\title{
Prospects and Feasibility of Diaspora Bond: The Case of Ghana
}

\author{
Lord Mensah $^{1}$ \\ ${ }^{1}$ Finance Department, University of Ghana Business School, Ghana \\ Correspondence: Lord Mensah, Finance Department, University of Ghana Business School, Ghana.
}

Received: March 4, 2019

Accepted: May 27, 2019

Online Published: June 9, 2019

doi:10.5430/ijfr.v10n4p25

URL: https://doi.org/10.5430/ijfr.v10n4p25

\begin{abstract}
This study sought to establish the rationale, feasibility, conditions, determinants and hindrances of a successful issuance of a diaspora bond by Ghana as a sovereign economic entity. The study also sought to assess the willingness of the Ghanaian diaspora to patronise a diaspora bond. A total of 12 financial institutions within Accra and 113 Ghanaians living in the diaspora were contacted using the purposive sampling method. The study finds that Ghana has patriotic citizens in the diaspora who are ready to patronize its diaspora bonds. It was also found that prospective investors of Ghana's diaspora bond find GDP growth and political stability as the most favourable indicators in pulling investors. The study concludes that though internal weaknesses and external threats exist, Ghana stands a good chance for a successful diaspora bond issue with an anticipated high patronage by Ghanaians in the diaspora.
\end{abstract}

Keywords: diaspora bonds, GDP growth, feasibility, bond prospects, debt to GDP

\section{Introduction}

Countries and sovereign states across the globe have tried to solicit overseas funds by varied mechanisms using a range of financial instruments which include financial notes, foreign currency deposits, derivatives, stocks, syndicated loans, grants and bonds to mention but a few. These funds have served a number of purposes many of which largely fall under these broad perspectives of financing developmental projects, strengthening a country's currency and maintain a favourable foreign exchange position and to improve a country's balance of payments position (Ketkar and Ratha, 2010).

Notable among these less-employed and unexploited foreign avenues of finance is the Diaspora Bond. A diaspora bond is a debt instrument issued by a country or potentially, a sub-sovereign entity or a private corporation, to raise financing from its overseas diaspora (Ketkar and Ratha, 2007, 2010). The historical trail of the Diaspora Bond is full proof of its low patronage and employment worldwide. Many countries have conceived and nursed the idea of a diaspora bond while a few of these countries ever made amends to apply the concept in practical terms. Few are still those who emerged successful in its implementation and the countable examples are Israel and India (Ketkar and Ratha, 2007; Ratha, 2007). India and Israel have collectively risen over $\$ 40$ billion using Diaspora bonds. African countries are virtually missing in the record of countries which have attempted to employ the diaspora bond. Kenya has harboured the idea of a diaspora bond since 2008, renewing its commitment in 2009 and 2011. Ethiopia also had little success in its diaspora bond issuance (Fatunle, 2013).

Given the wide range of financial (debt) instruments and sources of funds available to an economy in the present global "village" and international financial markets, it is only surprising that many economies (especially developing ones) still the on the limited sources and instruments of finance. However, this supposed thorn in the path of economic growth has come as a result of lamenting economies haven gotten traditionally stuck to a few sources of finance without taking the adventurous step of exploring other options of finance among which the diaspora bond is notable. Diaspora bonds are as yet not a widely used instrument in development finance (Fatunle, 2013; Okonjo-Iweala and Ratha, 2011; Ketkar and Ratha, 2007; Ratha, 2007). Many developing countries, however, have set up schemes to attract Foreign Currency Deposits (FCDs). While both Diaspora bonds and FCDs constitute foreign liabilities from the perspective of developing countries, there are vital differences between the two sources of finance. Diaspora bonds are typically long-dated securities which a country has to redeem only upon maturity. FCDs, in contrast, can be withdrawn at any time (Ketkar, 2006).

Most developing economies including Nigeria, Cote D'Ivoire, Ghana and Gabon and a number of Sub-Saharan African economies have resorted to Eurobonds rather than any country-specific diaspora bonds. Diaspora bonds 
address the untapped potential of diaspora savings and remittances, money that could be applied for development purposes in home countries (World Bank, 2011). Ghana for instance, has resorted to a few international development finance instruments, notable among them are Eurobonds (2007 and 2013), grants and aid, loans and even a stint with the Highly Indebted Poor Countries (HIPC). However, Ghana has never exploited Diaspora bonds as a mechanism to raise funds from the international market.

World Bank paper in March 2011 revealed that countries like Ghana, Kenya and Zambia, which have fairly large numbers of migrants living abroad in high-income countries, would particularly profit from issuing diaspora bonds (Okonjo-Iweala and Ratha, 2011). Kenya has been saddled by crisis of implementation while Ghana and Zambia have done very little to undertake such a venture. Though numerous studies have been done and several papers written on the diaspora bond and its contribution to development, to the best of my knowledge on existing literature, no study has assessed the prospect and feasibility of Ghana issuing a diaspora bond as an economic entity. This work therefore provides the platform to assess Ghana in this regard.

Moreover, a model or framework for assessing the prospect of countries in Sub-Saharan Africa in the issuance of diaspora bonds is lacking in literature. This work therefore provides a framework or model for assessing the prospect of issuing a diaspora bond in countries of similar characteristics as Ghana in Sub-Saharan Africa. Specifically, the study seeks to establish the rationale, feasibility, conditions, determinants and hindrances of a successful issuance of a diaspora bond by Ghana as a sovereign economic entity. A considerable number of studies have been done on diaspora bonds, but to the level of my knowledge, no study has yet assessed Ghana's potential, on a stand-alone basis, for a diaspora bond issue. This study therefore sets the stage for such analysis and assessment. This study also provides a framework or model for theory and practice in assessing the potential and prospect of countries in Sub-Saharan Africa to issue diaspora bonds.

\section{Literature Review}

A diversity of literature relates to the study of diaspora bonds in Africa and the World at large. Literature on diaspora bonds in Ghana is scanty and virtually non-existent. Sovereign states in most developing countries have expressed worry about the scarcity of financing options. Some developing countries have long desired to dissociate themselves from loans from the Bretton Woods Institutions (BWIs), namely; the International Monetary Fund (IMF), the World Bank and their affiliate institutions. Funds from these institutions have often been given in the form of loans, grants and developmental projects. This is because funds from these institutions have often been disbursed with certain requirements and conditions expected to be met by the recipient or borrowing country. This has made funds from the BWIs undesirable and unattractive to most developing countries whose national goals and objectives have often been diametrically opposed to that of the Bretton Wood Institutions. Nonetheless, developing countries have still continued to access funds from these Institutions with the underlying that financing options are few. This brings to bear the issue of sovereign financing options.

This review seeks to provide an overview of the existing body of knowledge on issues particularly related to sovereign financing options, the concept of the diaspora and diaspora bonds. The sub-themes to be considered include Countries and sovereign states across the globe have tried to raise funds both domestically and internationally through various financial vehicles. Locally, common sources of financing have been taxes, levies among other impositions. Domestic vehicles have also included money market instruments such as under-one-year treasury bills and capital market instruments such as mortgage securities, pension funds, treasury bonds and notes (Adrian et al, 2008). The practice of generating sovereign wealth and finance is as old as the institution of sovereign government itself and the practice has evolved over time.

Adrian et al (2008) focused primarily on macro stability issues at the broad macro level. They also compared the possible effects of different kinds of pools of capital, depending on how they are formed and, on their governance, rules and strategies. Sovereign Wealth Funds (SWF) are pools of assets owned and managed directly or indirectly by governments to achieve national objectives.

Not overlooking the effect of migration on the fund flows into Africa, Terrazas (2010) argues that the impact of migration on development has been more pronounced now than at any point in historical times. Financial flows from migrants and their descendants are at the heart of the relationship between migration and development. There is little doubt that remittances are a large and important intra-family financial flow that can have important effects on financial development. But it is also widely acknowledged that they represent only a fraction of the potential private financial flows originating from diasporas. Substantial evidence shows that diasporas hold substantial financial assets beyond their current income - in savings and retirement accounts, in property, debt and equity. Terrazas (2010) further asserts that though remittances tap the incomes of migrants, the greater challenge is to mobilise the wealth 
from the diaspora. Although circumstances across countries vary, financial markets in developing and emerging economies face several general challenges. Underdeveloped financial systems typically hinder formal savings and investment, which leads banks to prefer loans to large, safe borrowers and forces smaller, riskier borrowers into informal financial markets. Attracting foreign investors into many developing and emerging economies has proven difficult, at least prior to the recent economic crises, due to perceptions of high risk, volatile currencies, and information asymmetries.

Recent years have witnessed a renewed interest in the complex relationship between migration and development. The role of diasporas - defined broadly to include migrants and their descendants who maintain ties with their countries of origin - has often been overlooked or discussed only in general terms. Yet a growing body of evidence, both rigorous and anecdotal, suggests that diasporas play a critical role in supporting sustainable development by transferring resources, knowledge, and ideas back home, and in integrating their countries of origin into the global economy (Newland and Patrick, 2004 as cited in Terrazas, 2010).

Financial flows from migrants and their descendants are at the heart of the relationship between migration and development. Policy has mostly focused on migrants' remittances. There is little doubt that these remittances are large. Remittances to developing countries alone were estimated at nearly \$316 billion in 2009 - lower than the $\$ 355$ billion recorded in 2008 but still more than three times the $\$ 76$ billion recorded a decade earlier, in 1999. Despite a downturn due to the global economic crisis, remittances have proven much more stable and far less volatile than other private financial flows to developing and emerging economies (World Bank, 2010 as cited in Terrazas, 2010).

Migrant remittances are the most tangible and perhaps the least controversial link between migration and development. Remittances have become a major source of external development finance. In 2006, recorded remittances sent home by migrants from developing countries reached $\$ 206$ billion, more than double the level in 2001. The true scale of remittances, including unrecorded flows through formal and informal channels, is believed to be even larger. Remittances provide a convenient angle for approaching the complex migration agenda. They play an effective role in reducing poverty. Since remittances are personal flows from migrants to their friends and families, they tend to be well targeted to the needs of the recipients (Ratha, 2007).

Diaspora investors tend to have different perceptions of risk than non-diaspora investors. Given their homeland connections, diasporas may have better information about investment opportunities in their countries of origin and are less sensitive to exchange-rate risks than other investors, because they have domestic-currency obligations in their country of origin such as support payments to family members or running costs of domestic businesses, mortgages, or returns to domestic share-holders. They also may have a different time horizon. While most investors in emerging markets have a fairly short timeframe for profit expectations, many diaspora investors are willing to capture return on their investments over a longer period. They may even be willing to accept lower returns than they might otherwise secure, as a "patriotic discount," on investments in the homeland (Newland and Agunias, 2012).

A World Bank paper in March 2011 revealed that countries like Ghana, Kenya and Zambia, which have fairly large numbers of migrants living abroad in high-income countries, would particularly profit from issuing diaspora bonds (Okonjo-Iweala and Ratha, 2011). Kenya has been saddled by a crisis of implementation while Ghana and Zambia have done very little to undertake such a venture.

Diaspora bonds have often been confused with other debt instruments for foreign finance in that, various foreign debt instruments have certain features that run across the board thereby making distinction burdensome. This difficulty in distinction has been known to stifle the course of gathering data and records on diaspora bonds since it is mainly confused with foreign currency deposits and local currency deposits. Diaspora bonds are long-dated securities to be redeemed only at maturity unlike other deposits which may be withdrawn at any time. While foreign and local currency deposits exhort diaspora members to deposit money in domestic banks, diaspora bonds demand that they purchase foreign currency denominated bonds in international capital markets (Ketkar and Ratha, 2007).

It is worth mentioning that the high spirit of patriotism and sense of national engagement which characterise diaspora bonds is distinctive, and the success or failure of Diaspora bond literature may be divided into two. The first looks at the unique interest and the motivation of the diaspora. Diaspora bond investors evaluate the risks associated with sovereign bonds differently than other foreign investors. Lewis (1999) indicates that diaspora investors may be "home bias", and this may force them to purchase more domestic financial asset. This is in support of the assertion that non-monetary forces may push diasporas to invest heavily in their home country than what the traditional finance theory can predict. The second explores the possibility of not been able to pull their funds quickly at any exposure because of the characteristic of the bond (Mosley and Singer 2008). The proponent of the risk nature of 
diaspora bonds also argues that for bonds issued by sovereign states, investors may have limited enforcement mechanism to ensure repayment of the debt (Tomz 2012).

It is also believe that diasporas may be prepared to lend to their country of origin below the market interest rate and normally under some considerable conditions because of the sentiment towards their homeland (Riddle and Nielson 2011, Ketkar and Ratha 2007). Other literature contend that such bonds helps countries to develop their public infrastructure like education, health and possibly come out of financial crisis. Its normally help in countries whose instability and indebtedness prevent them from accessing funds from the formal capital market (Akkoyunlu and Nielson 2011).

As stated earlier, a diaspora bond is one of the least exploited sources of foreign finance. It is on this note that this paper tends to focus on Ghana on its prospect to tap into diaspora bond as a source of finance apart from the traditional existing traditional sources.

\section{Methodology}

The study is principally exploratory. It will involve collecting information by using questionnaires and interviews. It includes mainly qualitative analysis. According to Neuman (2007), a researcher may need to conduct an exploratory study in order to know enough to design and execute a second, more systematic and extensive study. Exploratory studies are valuable means of finding out 'what is happening; to seek new insights; to ask questions and to assess phenomena in a new light'. The study will be conducted among financial institutions in the city of Accra. The population refers to the entire group from whom answers are to be obtained. In this study, there are two sets of the population. The first set is made up of all financial institutions in the city of Accra while the second set consists of Ghanaians living in the diaspora.

The sample size refers to the subset of units in the population about which information is acquired. This study aims to contact about 10 financial institutions and about 100 Ghanaians living in the diaspora. Purposive sampling will be employed as the sampling technique, owing to the technical and defined nature of the subject under study. The study will mainly employ questionnaires and interviews. The questionnaire is designed to include both closed and open-ended questions. A closed-ended question both asks a question and gives the respondent fixed responses from which to choose. This guides the respondents in their choice of answers and also, the response choice can clarify question meaning for respondents. On the other hand, an open-ended question asks a question to which respondents can give any answer. This permits creativity, self-expression and richness of detail as well as enables the respondents to provide adequate answers to complex questions. Interviews would help in instances where questionnaires cannot serve the purpose. The use of primary data obtained through administration of questionnaires and interviews of targeted respondents would provide first-hand information on issues bordering on the research questions.

Qualitative methods of data analysis will be employed since the study seeks to delve into the prospect of a diaspora bond for Ghana. The SWOT framework will be employed as the major model for analysis. On the other hand, little use will be made of quantitative methods of analysis. However, descriptive statistics would be employed should the need arise. Certain difficulties may arise in the process of data collection. The cooperation and willingness of respondents to provide information may prove challenging. In spite of these and other unforeseen challenges which may arise, the validity and reliability of this study would be ensured.

\section{Data Analysis and Presentation of Findings}

Questionnaires were administered to a total of 12 financial institutions within Accra and 113 Ghanaians living in the diaspora. The twelve financial institutions are profiled in Table 1 below. Six $(50 \%)$ of these institutions are investment banks, two (16.7\%) are commercial banks, three $(25 \%)$ are non-bank financial institutions while one $(8.3 \%)$ is a consulting firm. Ninety one point seven percent $(91.7 \%)$ of the respondents from these institutions were able to convincingly define diaspora bonds while $83.3 \%$ were able to successfully point out the unique features of a diaspora bond that distinguishes it from other development finance instruments. This suggests that financial institutions generally have a good understanding of diaspora bonds and are knowledgeable on the subject matter. This table gives a fair view of the general understanding of Diaspora bonds among the institutions in our sample. It further gives us confident in asking further questions on the subject matter. 
Table 1. Profile of financial institutions selected for the study

\begin{tabular}{lll}
\hline Name & Type & Years of Existence \\
\hline Databank & Investment Bank & 24 \\
\hline National Investment Bank & Commercial Bank & 51 \\
\hline Frontline Capital Advisors & Investment Bank & 5 \\
\hline NDK Financial Services & NBFI & 23 \\
\hline Cedinomics Consulting & Consulting & 5 \\
\hline All-Time Capital & Investment Bank & 5 \\
\hline City Investments & NBFI & 19 \\
\hline EM Capital & Investment Bank & 4 \\
\hline Weston Capital & Investment Bank & 3 \\
\hline UT Bank & Commercial Bank & 17 \\
\hline IC Securities & Investment Bank & 13 \\
\hline IFS Financial Services & NBFI & 8 \\
\hline
\end{tabular}

On Ghana's strength to issues diaspora bonds, we asked whether Ghana's export base, governance, political stability, GDP or size of the economy, GDP growth, size of the population, public revenue to GDP ratio, tax policies and the business environment asked possible variables that put Ghana in a favourable position to issue a diaspora bond. All the twelve institutions saw the export base, size of the population and public revenue to GDP as variables which have no bearing on the success or otherwise of a diaspora bond issue. About $16.7 \%$ regarded governance as a variable which puts Ghana in a favourable position for an issue while $83.3 \%$ regarded governance as having no impact on the bond issue. Further, $75 \%$ of the institutions agreed that political stability was a favourable variable while $25 \%$ regarded it as having no impact. Surprisingly, 33\% saw GDP or the size of the economy as a favourable variable as $67 \%$ saw it as insignificant to a bond issue. On tax policies and business environment, $8.3 \%$ and $33.3 \%$ gave a favourable respond respectively. On GDP growth, $41.7 \%$ agreed is a favourable. The dominant and favourable internal variable for a successful diaspora bond issue are thus; political stability, GDP growth, and to a less considerable extent, GDP or size of the economy.

On the weakness against the issues of the diaspora bond, $75 \%$ of the institutions agreed that public debt to GDP ratio was an unfavourable variable while $25 \%$ regarded it as having no impact. About half of the institutional respondents saw Ghana's balance of payments position as an unfavourable. Inflation, interest rate movement and liquidity were regarded by $67 \%$ as unfavourable variables. Public expenditure to GDP and exchange rates were deemed by $58 \%$ as unfavourable while $42 \%$ deemed them not to have any effect. The dominant unfavourable internal variables against a successful diaspora bond issue in order of relevance are public debt to GDP, inflation, interest rate movement, liquidity, public expenditure to GDP, exchange rates, and balance of payments position.

We also ascertain from our institutional respondents the possible opportunities and threats in the Global environment in the issuance of the diaspora bond. Table 2 a shows that $75 \%$ of respondents identified credit ratings as a threat to a diaspora bond issue while $25 \%$ saw it as an opportunistic factor. Ghana's credit ratings have suffered a dim outlook recently from Fitch and Standard and Poor's following the worsening of debt, current account and budget deficits.

Table 2a. Credit ratings

\begin{tabular}{llllll}
\hline & & Frequency & Percent & Valid Percent & Cumulative Percent \\
\hline \multirow{2}{*}{ Valid } & Opportunistic factor & 3 & 25.0 & 25.0 & 25.0 \\
\cline { 2 - 6 } & Threat & 9 & 75.0 & 75.0 & 100.0 \\
\cline { 2 - 5 } & Total & 12 & 100.0 & 100.0 & \\
\hline
\end{tabular}


Table 2b. Size of the diaspora

\begin{tabular}{llllll}
\hline & & Frequency & Percent & Valid Percent & Cumulative Percent \\
\hline Valid & Opportunistic factor & 6 & 50.0 & 50.0 & 50.0 \\
\cline { 2 - 6 } & Threat & 1 & 8.3 & 8.3 & 58.3 \\
\cline { 2 - 5 } & Neutral & 5 & 41.7 & 41.7 & 100.0 \\
\cline { 2 - 5 } & Total & 12 & 100.0 & 100.0 & \\
\hline
\end{tabular}

Table $2 \mathrm{~b}$ reports that $50 \%$ of respondents identified the size of Ghana's diaspora as an opportunistic factor, $41.7 \%$ saw it as a threat while $8.3 \%$ said it had no effect on a diaspora bond issue.

Table 2c. Income levels of the diaspora

\begin{tabular}{llllll}
\hline & Frequency & Percent & Valid Percent & Cumulative Percent \\
\hline Valid & Opportunistic factor & 5 & 41.7 & 41.7 & 41.7 \\
\cline { 2 - 5 } & Threat & 2 & 16.7 & 16.7 & 58.3 \\
\cline { 2 - 5 } & Neutral & 5 & 41.7 & 41.7 & 100.0 \\
\cline { 2 - 5 } & Total & 12 & 100.0 & 100.0 & \\
\hline
\end{tabular}

Table 2d. Patriotic spirit of the diaspora

\begin{tabular}{llllll}
\hline & & Frequency & Percent & Valid Percent & Cumulative Percent \\
\hline \multirow{2}{*}{ Valid } & Opportunistic factor & 9 & 75.0 & 75.0 & 75.0 \\
\cline { 2 - 6 } & Neutral & 3 & 25.0 & 25.0 & 100.0 \\
\cline { 2 - 5 } & Total & 12 & 100.0 & 100.0 & \\
\hline
\end{tabular}

In terms of the income levels of the diaspora, $41.7 \%$ of respondents identified it as an opportunistic factor while another 41.7 also deemed it a threat. 16.7\% said income levels of the Ghanaian diaspora have no effect on a diaspora bond issue. Seventy-five percent $75 \%$ regard the patriotic spirit of the diaspora as a catalyst which can positively support a diaspora bond issuance. Respondents largely regard the Ghanaian diaspora as patriotic and supportive of their nation.

Table 2e. Confidence of the diaspora in the economy

\begin{tabular}{llllll}
\hline & & Frequency & Percent & Valid Percent & Cumulative Percent \\
\hline Valid & Opportunistic factor & 3 & 25.0 & 25.0 & 25.0 \\
\cline { 2 - 6 } & Threat & 7 & 58.3 & 58.3 & 83.3 \\
\cline { 2 - 5 } & Neutral & 2 & 16.7 & 16.7 & 100.0 \\
\cline { 2 - 5 } & Total & 12 & 100.0 & 100.0 & \\
\hline
\end{tabular}

We also ask questions in relation to the confidence that investors might have in the economy. About fifty-eight percent $(58.3 \%)$ identified the confidence of the diaspora in the Ghanaian economy as a threat to a bond issue while 
$25 \%$ saw it as an opportunistic factor. However, $16.7 \%$ do not think the variable has any bearing on a diaspora bond issue.

On the spatial distribution of the diaspora, $75 \%$ of institutional respondents think that the spatial distribution of the Ghanaian diaspora has no impact on the issue while $16.7 \%$ and $8.3 \%$ see it as an opportunistic factor and threat respectively (shown in the Table $2 \mathrm{f}$ below) .

Table 2f. Spatial distribution of the diaspora

\begin{tabular}{llllll}
\hline & Frequency & Percent & Valid Percent & Cumulative Percent \\
\hline Valid & Opportunistic factor & 2 & 16.7 & 16.7 & 16.7 \\
\cline { 2 - 6 } & Threat & 1 & 8.3 & 8.3 & 25.0 \\
\cline { 2 - 6 } & Neutral & 9 & 75.0 & 75.0 & 100.0 \\
\cline { 2 - 6 } & Total & 12 & 100.0 & 100.0 & \\
\hline
\end{tabular}

Table 2g. International tax laws

\begin{tabular}{llllll}
\hline & Frequency & Percent & Valid Percent & Cumulative Percent \\
\hline Valid & Opportunistic factor & 2 & 16.7 & 16.7 & 16.7 \\
\cline { 2 - 6 } & Threat & 5 & 41.7 & 41.7 & 58.3 \\
\cline { 2 - 5 } & Neutral & 5 & 41.7 & 41.7 & 100.0 \\
\cline { 2 - 5 } & Total & 12 & 100.0 & 100.0 & \\
\hline
\end{tabular}

Table $2 \mathrm{~h}$. SEC regulations in foreign jurisdictions

\begin{tabular}{llllll}
\hline & Frequency & Percent & Valid Percent & Cumulative Percent \\
\hline Valid & Opportunistic factor & 1 & 8.3 & 8.3 & 8.3 \\
\cline { 2 - 6 } & Threat & 6 & 50.0 & 50.0 & 58.3 \\
\cline { 2 - 6 } & Neutral & 5 & 41.7 & 41.7 & 100.0 \\
\cline { 2 - 5 } & Total & 12 & 100.0 & 100.0 & \\
\hline
\end{tabular}

International tax laws are seen by $41.7 \%$ of respondents as a threat while another $41.7 \%$ also see it as insignificant. $16.7 \%$ also deem it an opportunistic factor (see Table $2 \mathrm{~h}$ above).

Fifty percent (50\%) hold regulations of the Securities and Exchange Commission in foreign jurisdictions as a threat to a successful issue. This is in line with Chander's (2001) emphasis on the need for a diaspora bond issuer to avoid the threat and burden of multiple jurisdictions. This threat underpins India's decision to forego SEC registration during its diaspora bond issue for the avoidance of both U.S. laws and U.S. court procedures. In spite of the reality of the threat of multiple jurisdictions, $41.7 \%$ of respondents saw it as a variable with no impact on a diaspora bond issue while $8.3 \%$ deemed it an opportunistic factor.

On the side on the diaspora respondents, questionnaires were administered to 113 Ghanaians living in the diaspora at the departure lounge of the Kotoka International Airport. Seventy-one representing $(62.8 \%)$ of the respondents are male while $42(37.2 \%)$ are female. Fifty- six percent (56\%) are married while $44 \%$ are single. Monthly incomes were recorded as gross incomes owing to the differentials in tax policies in different jurisdictions. Additional profiling of the 113 respondents is set forth in the following Tables and Figures. From Figure 1, it is clear that the average of our respondent who resides in the diaspora is between thirty and Forty years. These gives some confidence to the possibility of issuing long term diaspora bond since young age will like to invest long term. We also looked at the 
education level (Table 3a) of our respondent and it was clear that almost fifty percent had finished university education, and it is enough to say that our respondents were not novice.

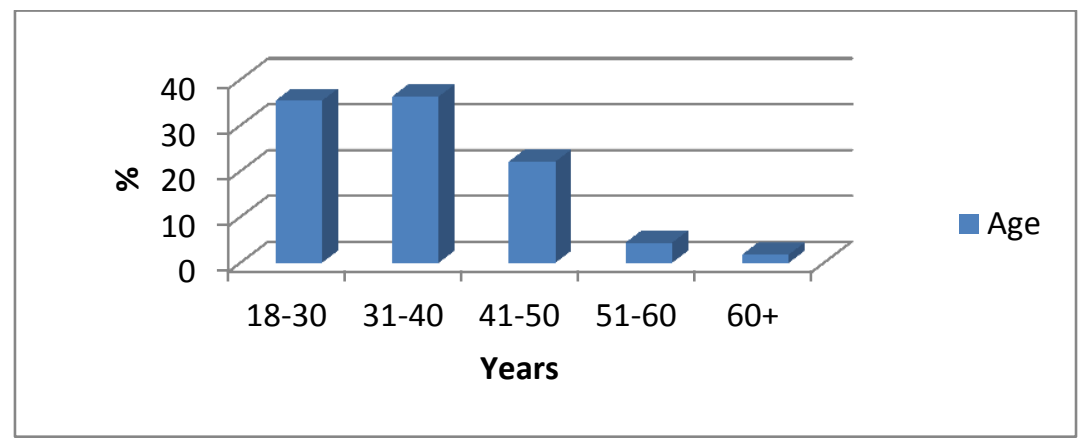

Figure 1. Age of respondents

Table 3a. Highest level of education

\begin{tabular}{llllll}
\hline \multirow{3}{*}{ Valid } & & Frequency & Percent & Valid Percent & Cumulative Percent \\
\cline { 2 - 6 } & Primary & 16 & 14.2 & 14.2 & 14.2 \\
\cline { 2 - 6 } & Secondary & 32 & 28.3 & 28.3 & 42.5 \\
\cline { 2 - 5 } & Tertiary & 56 & 49.6 & 49.6 & 92.0 \\
\cline { 2 - 5 } & Other & 9 & 8.0 & 8.0 & 100.0 \\
\cline { 2 - 5 } & Total & 113 & 100.0 & 100.0 & \\
\hline
\end{tabular}

Table 3b. Monthly income

\begin{tabular}{|c|c|c|c|c|c|}
\hline & & Frequency & Percent & Valid Percent & Cumulative Percent \\
\hline \multirow[t]{5}{*}{ Valid } & Below $\$ 500$ & 30 & 26.5 & 26.5 & 26.5 \\
\hline & $\$ 501-1000$ & 50 & 44.2 & 44.2 & 70.8 \\
\hline & $\$ 1001-3000$ & 31 & 27.4 & 27.4 & 98.2 \\
\hline & $\$ 3001-5000$ & 2 & 1.8 & 1.8 & 100.0 \\
\hline & Total & 113 & 100.0 & 100.0 & \\
\hline
\end{tabular}

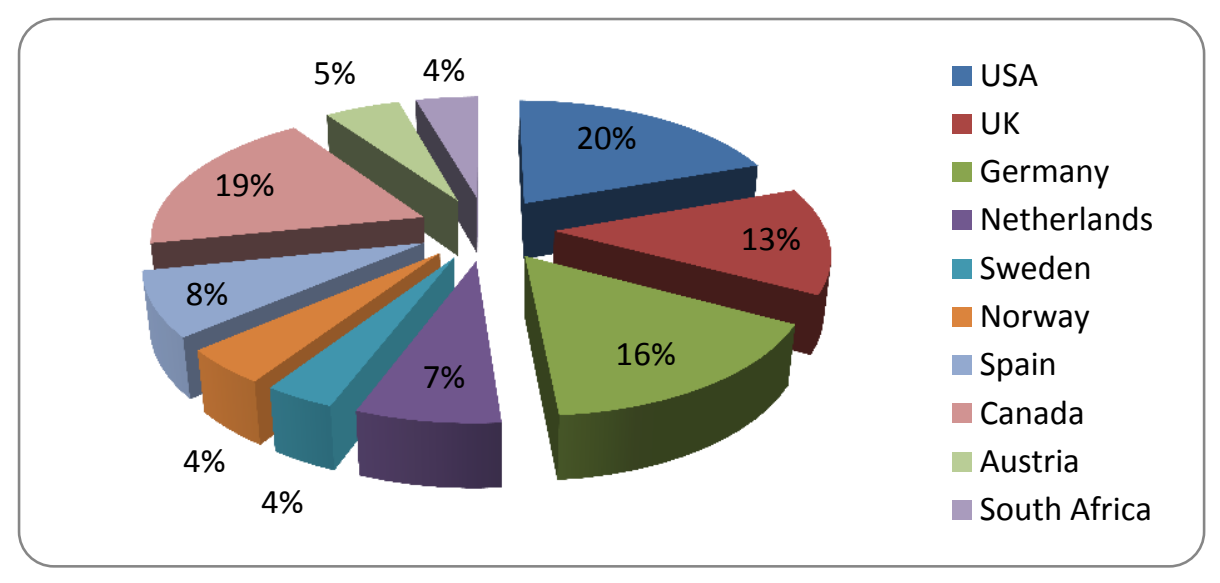

Figure 2. Foreign country of residence 
To ascertain the investment capabilities of our respondent, we record their income level. For easy comparison and analysis, all income figures were converted to the United States Dollars, at the spot exchange rates at the close of trading on $3^{\text {rd }}$ June, 2018 (Bloomberg). Clearly, most of our respondents show income level of 3000 USD and below (see Table $3 \mathrm{~b}$ below). Figure 2 shows the distribution of respondents across different countries in the diaspora.

The confidence of the Ghanaian diaspora in the Ghanaian economy was also ascertained in this study. Sixty percent $(60 \%)$ of respondents believe Ghana has not developed in the last five years while $40 \%$ think Ghana has developed in the last five years. $68 \%$ are confident Ghana will develop in the next five years while $32 \%$ lack confidence in the economy (see Tables $3 \mathrm{c}$ and $3 \mathrm{~d}$ ). Thus, Ghanaians living in the diaspora are largely confident in the future of the Ghanaian economy.

Table 3c. Has Ghana developed in last five years

\begin{tabular}{llllll}
\hline & & Frequency & Percent & Valid Percent & Cumulative Percent \\
\hline \multirow{7}{*}{ Valid } & Yes & 45 & 39.8 & 39.8 & 39.8 \\
\cline { 2 - 6 } & No & 68 & 60.2 & 60.2 & 100.0 \\
\cline { 2 - 6 } & Total & 113 & 100.0 & 100.0 & \\
\hline
\end{tabular}

Table 3d. Will Ghana develop in next five years

\begin{tabular}{llllll}
\hline & & Frequency & Percent & Valid Percent & Cumulative Percent \\
\hline Valid & Yes & 77 & 68.1 & 68.1 & 68.1 \\
\cline { 2 - 6 } & No & 36 & 31.9 & 31.9 & 100.0 \\
\cline { 2 - 6 } & Total & 113 & 100.0 & 100.0 & \\
\hline
\end{tabular}

In Table 3e, we report the willingness of the respondent to lend to sovereign Ghana. Out of the 113 respondents, 85 (75\%) are willing to lend to Ghana for five years while $28(25 \%)$ are not willing to lend to Ghana. The respondents' strongest basis for lending to Ghana is represented in Figure 3. Clearly, 27.4\% are motivated to lend to earn interest, $20.4 \%$ would lend for development while $18.6 \%$ would lend to help their country as Ghanaians. This suggests that the motivation of the diaspora to lend is gradually shifting from just patriotism to the idea of earning interest on loaned funds.

Table 3e. Would you lend to Ghana for 5 years

\begin{tabular}{|c|c|c|c|c|c|}
\hline & & Frequency & Percent & Valid Percent & $\begin{array}{l}\text { Cumulative } \\
\text { Percent }\end{array}$ \\
\hline \multirow[t]{4}{*}{ Valid } & Yes & 85 & 75.2 & 75.2 & 75.2 \\
\hline & No & 28 & 24.8 & 24.8 & 100.0 \\
\hline & Total & 113 & 100.0 & 100.0 & \\
\hline & & $9 \%$ & & $\begin{array}{l}\text { - I won't lend to } \\
\text { - To help my co } \\
\text { - For developm } \\
\text { - To earn intere } \\
\text { - To save for th }\end{array}$ & $\begin{array}{l}\text { hana } \\
\text { try as a Ghanaian } \\
\text { on my investment } \\
\text { uture }\end{array}$ \\
\hline
\end{tabular}

Figure 3. Strongest basis for lending to Ghana 
In terms of the period within which the respondents are willing to lend to Ghana, $44.2 \%$ are willing to lend for 5 years, $19.5 \%$ for 7 years, $9.7 \%$ for 10 years and $1.8 \%$ for 15 years (see Table $3 \mathrm{f}$ ). This presupposes that, a 5 -year horizon will be most appropriate for a Ghana diaspora bond issue.

Table 3f. How many years would you be willing to lend

\begin{tabular}{|c|c|c|c|c|c|}
\hline & & Frequency & Percent & Valid Percent & Cumulative Percent \\
\hline \multirow[t]{6}{*}{ Valid } & & 28 & 24.8 & 24.8 & 24.8 \\
\hline & 5 & 50 & 44.2 & 44.2 & 69.0 \\
\hline & 7 & 22 & 19.5 & 19.5 & 88.5 \\
\hline & 10 & 11 & 9.7 & 9.7 & 98.2 \\
\hline & 15 & 2 & 1.8 & 1.8 & 100.0 \\
\hline & Total & 113 & 100.0 & 100.0 & \\
\hline
\end{tabular}

Table 3g. Would you lend to Ghana for relatively lower interest

\begin{tabular}{|c|c|c|c|c|c|}
\hline & & Frequency & Percent & Valid Percent & Cumulative Percent \\
\hline \multirow[t]{4}{*}{ Valid } & & 28 & 24.8 & 24.8 & 24.8 \\
\hline & Yes & 59 & 52.2 & 52.2 & 77.0 \\
\hline & No & 26 & 23.0 & 23.0 & 100.0 \\
\hline & Total & 113 & 100.0 & 100.0 & \\
\hline
\end{tabular}

Further, in Table 3g, $52.2 \%$ of respondents are willing to lend to Ghana even if the interest on the Ghanaian bond is lower than the rate on other securities with similar features on the market. This demonstrates the high sense of patriotism and willingness to patronise a diaspora bond issue among the Ghanaian diaspora.

\section{Conclusion and Recommendations}

The study looked at the prospect of a Ghanaian diaspora bond. The focus of the study was to assess Ghana's chances of issuing a diaspora bond successfully and the willingness of the Ghanaian in the diaspora to patronise the bond issue. The research was designed as an exploratory one because it had the objective of shedding more light on the chosen topic. The population consisted of two sets namely; financial institutions in Accra and Ghanaians living in the diaspora. 12 financial institutions in Accra and 113 Ghanaians living in the diaspora constituted the sample size. Primary data was collected from these institutions and Ghanaians living abroad through well-designed questionnaires that incorporated both closed and open- ended questions. Qualitative methods of data analysis were mainly employed since this study focuses on prospect and patronage of diaspora bonds.

This study has established that Ghana has a patriotic diaspora who are ready to support their native country through a diaspora bond. Specifics emanating from the study are as follows:

- There is a high sense of patriotism and willingness to patronise a diaspora bond issue among the Ghanaian diaspora.

- The dominant favourable internal variables for a successful diaspora bond issue are political stability and GDP growth.

- The dominant unfavourable internal variables against a successful diaspora bond issue are public debt to GDP, inflation, interest rate movement, liquidity, public expenditure to GDP, exchange rates, and balance of payments position.

- Size of the diaspora and income levels of the diaspora serves both as threats and opportunistic factors. 
- The major threats identified are credit ratings, confidence of the diaspora in the economy, international tax laws and Securities and Exchange Commission regulations in foreign jurisdictions.

- The patriotism of the Ghanaian diaspora is a distinctive opportunistic factor.

- The motivation of the diaspora to lend is gradually shifting from just patriotism to the idea of earning interest on loaned funds.

- The Ghanaian diaspora generally thinks Ghana has not developed in the past five (5) years.

- The Ghanaian diaspora is generally confident in the future of the Ghanaian economy.

- A 5-year horizon will be most appropriate for a Ghana diaspora bond issue.

The above analysis points to the conclusion that Ghanaian's in the diaspora are patriotic and are willing to support a diaspora bond issue. Though threats and weaknesses abound externally and internally respectively, Ghana stands a good chance of issuing a diaspora bond successfully.

The above findings corroborate the "home bias theory" and the fundamental drivers of a successful bond issue. It is clear from the findings that diaspora attachment to their home country can provide the opportunity for a successful diaspora bond issue. The findings also support the improvement in the economic fundamentals could be a catalyst for a success of diaspora bond.

This study is unique and improves on the existing literature by combining the investor, the issue country and the global perspectives in assessing the possibility of issuing successful diaspora bond.

From the above findings, the following measures are recommended to ensure high patronage and success of a Ghana diaspora bond issue:

- The central bank must ensure that monetary policies achieve macroeconomic stability.

- The government must maintain fiscal discipline to improve debt to GDP ratio.

- Improving balance of payments and budget deficits must be prioritized and embedded in policy goals.

- Seminars and conferences must be organized by the government to engage the diaspora in national development.

- $\quad$ Efforts must be made to address concerns raised by credit rating agencies.

The study therefore sets the stage for future research in that, the study can be replicated in other areas and regions to assess the prospect of issuing diaspora bonds. This study chooses various macro variables and aligns these variables with the SWOT model in assessing the chances of success in a diaspora bond issue. The tailored SWOT model used here can be applied to countries such as Kenya, Zambia, Nigeria, Gabon, Thailand, Jamaica to mention but a few. It also establishes a basis for comparative studies of the prospect and patronage of diaspora bonds in Ghana relative to other countries and regions of the world.

Furthermore, the study used a sample of 113 Ghanaians living in the diaspora and 12 financial institutions due to financial constraints. Though there was consensus among respondents on many of the issues raised, future studies can be conducted on the topic with a larger sample size which will provide a stronger basis for generalising findings.

The study concludes that though internal weaknesses and external threats exist, Ghana stands a good chance for a successful diaspora bond issue with an anticipated high patronage by the Ghanaian diaspora.

\section{References}

Aboagye, A. Q. Q. (2013). The Capital Market and Economic Growth and Development of Ghana. Presented at The Ghana Capital Market Conference. Department of Finance. University of Ghana.

Adrian, B., Hu, Y., \& Yermo, J. (2008). Sovereign Wealth and Pension Fund Issues. Financial Market Trends. Organization of Economic Cooperation and Development (OECD). https://doi.org/10.1787/fmt-v2008-art5-en

Akkoyunlu, S., \& Nilsen, T. (2012). An empirical analysis of diaspora bonds. Research Paper 3, The graduate institute program for the study of global migration. Geneva.

Bank of Ghana. (2013). Prospectus for the Issue of GH $\notin 100$ Million Government of Ghana 7-Year Fixed Rate Bond. Notice No. BG/TD/2013/52.

Bank of Ghana. (2013). Prospectus for the Issue of GH $₫ 600$ Million Government of Ghana 5-Year Fixed Rate Bond. Notice No. BG/TD/2013/42. 
Bank of Ghana. (2013). Publications: Quarterly Bulletin.

Business Monitor International. (2011). Eurobonds: Favouring Nigeria and Côte d'Ivoire. Emerging Markets Monitor, Business Monitor International.

Chander, A. (2001). Diaspora Bonds. New York University Law Review, 75, 1005-1099.

Fatunle, D. M. (2013). Diaspora Bonds: New Emerging Market Capital. Diaspora Debate. The Royal African Society.

Jewish Virtual Library. (2008). Israel Business \& Economy: State of Israel Bonds. The Gale Group.

Kayode-Anglade, S., \& Spio-Garbrah, N. (2012). Diaspora Bonds: Some Lessons for African Countries. Africa Economic Brief. African Development Bank.

Ketkar, L. S. (2006). Diaspora Bonds: Track Record and Potential. Funded by the World Bank. https://doi.org/10.1596/1813-9450-4311

Ketkar, L. S., \& Ratha, D. (2007). Development Finance via Diaspora Bonds: Track Record and Potential. The World Bank Development Prospects Group. Migration and Remittances Team. https://doi.org/10.1596/1813-9450-4311

Ketkar, L. S., \& Ratha, D. (2010). Diaspora Bonds: Tapping the Diaspora During Difficult Times. Journal of International Commerce, Economics and Policy, 1(2). 251-263. https://doi.org/10.1142/S1793993310000147

Lewis, K. (1999). Trying to Explain Home Bias in Equities and Consumption. Journal of Economic Literature, 37, 571-608. https://doi.org/10.1257/jel.37.2.571

Ministry of Finance and Economic Planning (MOFEP). (2013). The Ghana 2013 Eurobond Transaction. Eurobond Press Briefing.

Ministry of Finance and Economic Planning. (2007). The Government of Ghana 2007 Eurobond Prospectus.

Mosley, L., \& Singer, D. (2008). Taking Stock Seriously: Equity Market Performance, Government Policy, and Financial Globalization. International Studies Quarterly, 52(2), 405-425. https://doi.org/10.1111/j.1468-2478.2008.00507.x

Mullings, B. (2012). Governmentality, Diaspora, Assemblages and the Ongoing Challenge of "Development". Antipode, 44(2), 406-427. https://doi.org/10.1111/j.1467-8330.2010.00857.x

Newland, K., \& Agunias, D. R. (2012). Developing a Road Map for Engaging Diasporas in Development. A Handbook for Policymakers and Practitioners in Home and Host Countries. Migration Policy Institute.

Newland, K., \& Patrick, E. (2004). Beyond Remittances: The Role of Diaspora in Poverty Reduction in Their Countries of Origin. Washington DC and London. MPI and the UK Department for International Development (DFID).

Okonjo-Iweala, N., \& Ratha, D. (2011). A Bond for the Homeland.

Probst, T. (2012). Learning from Nepal's First Diaspora Bond Issuances. Essay on Development Policy.

Ratha, D., \& Plaza, S. (2011). Harnessing Diasporas. Finance and Development.

Riddle, L. T., \& Nielsen, M. (2011). Bridging the Divide between Diaspora Investment Interest and Action. https://doi.org/10.1108/20450621111124406

Terrazas, A. (2010). Diaspora Investments in Developing and Emerging Country Capital Markets: Patterns and Prospects. Migration Policy Institute.

The World Bank. (2003). Diaspora Bonds: Special Purpose Commercial Borrowing - Indian Experience.

Tomz, M. (2007). Reputational and International Cooperation: Sovereign Debt Across three Centuries. Princeton: Princeton University press.

World Bank. (2010). Remittances Data. World Bank Development Prospects Group.

World Bank. (2011). Diaspora Bonds Gain Momentum. Sponsored by Poverty Reduction and Economic Management Network.

Xavier, V. B., \& Stijn, V. (2012). A briefing on Eurobonds. European Policy Brief. Egmont Royal Institute for International Relations. 